\title{
Culture of Immature Embryos of Coconut, Cocos nucifera L: Callus Proliferation and Somatic Embryogenesis
}

\section{SEETHA KARUNARATNE and KAUSHALYA PERIYAPPERUMA}

\author{
Tissue Culture Unit, Coconut Research Institute \\ Lunuwila, (Sri Lanka)
}

The culture of immature embryos of coconut (Cocos nucifera $\mathrm{L}$ var. typica) was attempted with a view to developing a technique for clonal propagation. Embryos, 6-7 months postanthesis produced whitish, compact, embryogenic callus tissues in the presence of 12-20 $\mu \mathrm{M}$ 2,4-D. Callus was maintained by subculture on a medium of the same composition. About $50 \%$ of the callus cultures produced globular embryos when transferred to $8 \mu \mathrm{M}$ 2,4-D. Embryos in $22 \%$ of these cultures germinated and produced shoots, $6 \mathrm{~mm}$ long, when 6 benzylamino purine and kinetin (10 $\mu \mathrm{M}$ each) were incorporated into the culture medium.

The age of the embryo was an important factor determining callus proliferation and subsequent embryogenesis. More than 50\% of embryos excised from 6-7-month-old nuts produced embryogenic callus tissues. Five to six-month-old nuts were not mature enough for excising the embryos. Embryos from older nuts ( 8 months and above) germinated in culture. Only a small portion of the immature embryo produced embryogenic callus tissues. The future root region proliferated into a brownish callus which in turn produced roots profusely. The cotyledon of the immature embryo expanded and developed into a haustorium without any sign of callus formation. The shoot apex produced a few plumular leaves but no callusing was observed.

Key words: Cocos nucifera ; immature embryo; somatic embryogenesis; embryogenic callus; cotyledon; postanthesis.

Reprinted from Plant Science 62 (1989) 247-253 with kind permission of Elsevier Scientific Publishers Ireland Ltd. 


\section{INTRODUCTION}

The coconut palm (Cocos nucifera) is one of the most important crops in many tropical countries. As palms do not produce suckers, seed is the only available means of propagation. The coconut is highly heterozygous, long lived and has a very long juvenile phase. Breeding for crop improvement is thus a difficult and long-term process. Vegetative propagation, employing tissue culture techniques, offers a means of cloning improved planting material within a short period.

Coconut tissue culture has a long history dating back to the 1950's [1-5]. A few accomplishments have been made in the recent past and plant regeneration was reported from cultured flower meristems [7] and leaf explants [6]. de Guzman et al. [8], D' Souza [9] and Gupta et al. [10] cultured zygotic embryos of the coconut and reported development of 'shoot like' structures from the callus derived from the cotyledon sheath. These workers appeared to have used mature zygotic embryos for their experiments. The culture of immature embryos from very tender nuts has not been reported. This investigation on the culture of immature embryos indicates that the immature embryo explant is a tissue holding great potential for propagation.

\section{MATERIALS AND METHODS}

Tender nuts of coconut (Cocos nucifera $\mathrm{L}$ var. typica) harvested 6-8 months after pollination, were used as the source of embryos. Nuts were husked and washed with a $5 \%$ household detergent solution and embryos were dissected under aseptic conditions. Embryos at this stage were partially gelatinous and roughly spherical with diameters ranging from 0.2 $1.5 \mathrm{~mm}$. Embryos were transferred to screw capped vials (one per vial) containing $10 \mathrm{ml}$ of culture medium and incubated at $28-30^{\circ} \mathrm{C}$ in the dark.

The basal medium was developed following the broad spectrum tissue culture trials of de Fossard [11]. In addition, it contained $30 \mathrm{~g} / 1$ sucrose and $0.25 \%$ activated charcoal. The $\mathrm{pH}$ was adjusted to 5.8 with $0.1 \mathrm{~N} \mathrm{NaOH}$, before solidifying with $0.8 \%(w / v)$ agar. The composition of the complete medium is given in Table I.

The growth hormones tested were, $10-30 \mu \mathrm{M}$ BAP and $6-100 \mu \mathrm{M} 2,4-\mathrm{D}$. Media were sterilized by autoclaving at $1 \mathrm{~kg} \mathrm{~cm} 2$ for $15 \mathrm{~min}$. A minimum of 15 replicates each consisting of one embryo were used for each treatment.

\section{RESULTS AND DISCUSSION}

\section{Callus origin}

After $1-2$ weeks in culture, the immature embryos produced tiny swellings. These swellings gradually developed into highly convoluted, white, transparent calluses within 2 - 4 weeks (Fig. 1C). Embryogenic callus originated from a tissue in the close vicinity of the cotyledon (Fig. IA,B). This region may be identified as the 'cotyledonary node' of the future seedling (Fig. 2B). At the time of culturing, the developing cotyledon and the shoot apex of 
the embryo were visible (Fig. 2A). These organs continued their normal development when incubation was prolonged in the same medium and no callus was formed. The shoot apex produced a few plumular leaves but plant formation was incomplete. The root region produced a fast growing, brownish, highly rhizogenic callus. The cotyledon rapidly developed into a greenish spongy haustorium in culture and no callus was produced. When the haustorium tissues were subcultured, they in turn expanded enormously as during germination of the nut in situ. This further indicates that the origin of the embryogenic callus is not strictly a cotyledon tissue. This is in contrast to a report of previous workers $[8,9]$ that the callus origin was the cotyledon sheath. Other tissues in close proximity to the cotyledon are generally highly morphogenetic and plants have been successfully regenerated from oil seed rape [12] ragi [13] wheat [14] and soybean [15].

Table 1. Composition of the culture medium

\begin{tabular}{|c|c|}
\hline Constituents & Conc. \\
\hline \multicolumn{2}{|c|}{ Macronutrient elements (mM) } \\
\hline $\mathrm{NH}_{4} \mathrm{NO}_{3}$ & 20 \\
\hline $\mathrm{KNO}_{3}$ & 20 \\
\hline $\mathrm{NaH}_{2} \mathrm{PO}_{4}$ & 2 \\
\hline $\mathrm{CaCl}_{2}$ & 3 \\
\hline $\mathrm{MgSO}_{4}$ & 3 \\
\hline \multicolumn{2}{|c|}{ Micronutrient elements (mM) } \\
\hline $\mathrm{H}_{3} \mathrm{BO}_{3}$ & 150 \\
\hline $\mathrm{MnSO}_{4}$ & 100 \\
\hline $\mathrm{ZnSO}_{4}$ & 40 \\
\hline $\mathrm{CuSO}_{4}$ & 1.5 \\
\hline $\mathrm{Na}_{2} \mathrm{MOO}_{4}$ & 1.0 \\
\hline $\mathrm{CoCl}_{2}$ & 1.0 \\
\hline $\mathrm{KI}$ & 5.0 \\
\hline $\mathrm{FeSO}_{4}$ & 100 \\
\hline $\mathrm{Na}_{2} \mathrm{EDTA}$ & 100 \\
\hline $\mathrm{Na}_{2} \mathrm{SO}_{4}$ & 650 \\
\hline \multicolumn{2}{|c|}{ Growth factors (mM) } \\
\hline Inositol & 600 \\
\hline Nicotinic acid & 40 \\
\hline Thiamine $-\mathrm{HCl}$ & 40 \\
\hline Biotin & 1.0 \\
\hline D-Ca-Pantothenate & 5.0 \\
\hline Pyridoxine $-\mathrm{HCl}$ & 6.0 \\
\hline Riboflavin & 10 \\
\hline Ascorbic acid & 10 \\
\hline \multicolumn{2}{|c|}{ Amino acids (mM) } \\
\hline L-Cysteine - $\mathrm{HCl}$ & 120 \\
\hline Glycine & 50 \\
\hline
\end{tabular}



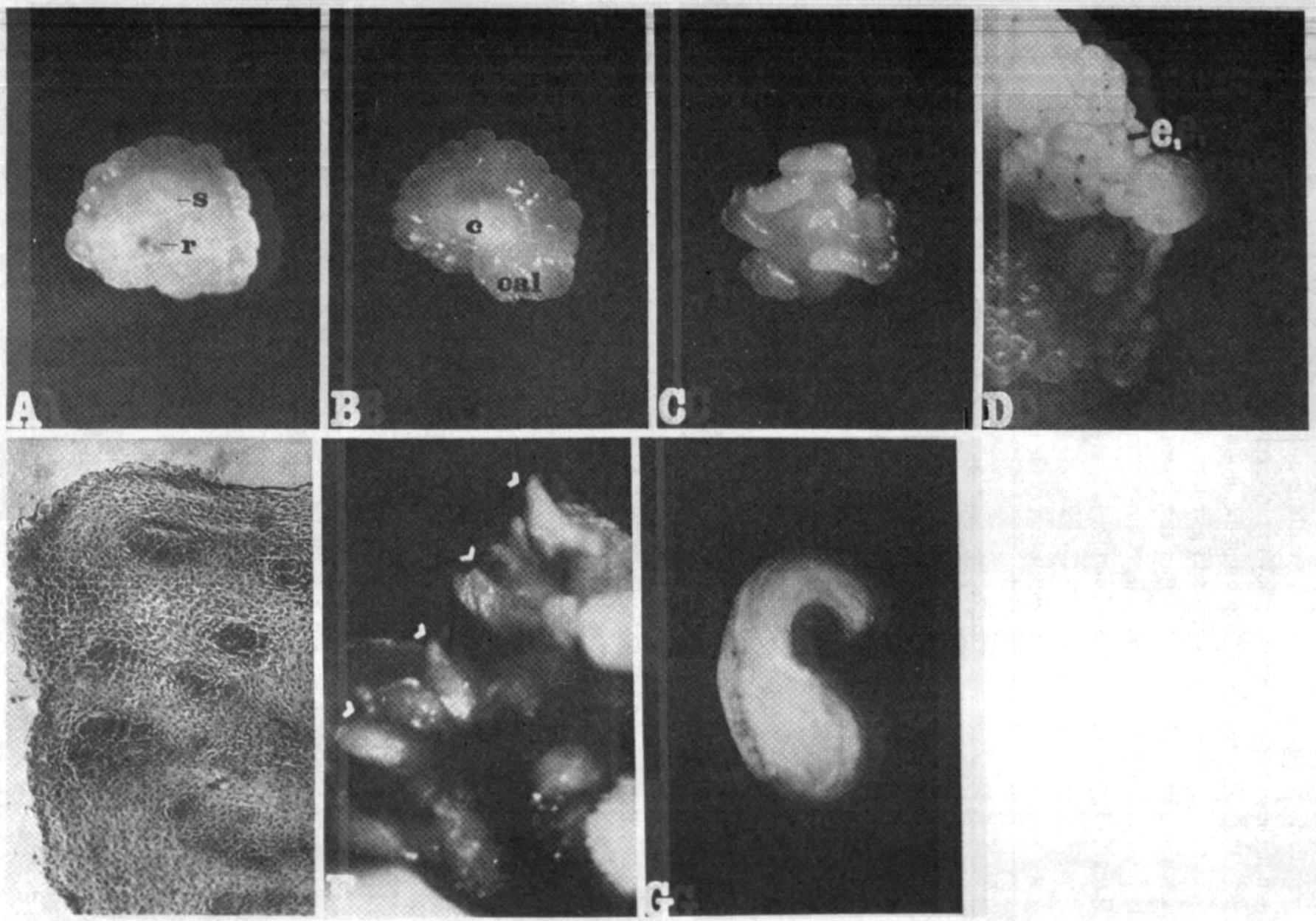

Fig. 1. Callusing and somatic embryogenesis from immature zygotic embryo of coconut. (A) Shoot (s) and root end (r) of the callusing zygotic embryo. (B) Bottom view of specimen A, showing its cotyledon (c) developing into a haustorium. cal, callus. (C) Convoluted callus. (D) Globular embryos (e) developing from callus. (E) Callus in section showing embryos eut obliquely ( $\times$ 78). (F) Sprouting somatic embryos ( $\times 3.9$ ). (G) A sprouting somatic embryo in seetion. Note developing leaves $(\times 4.5)$. 

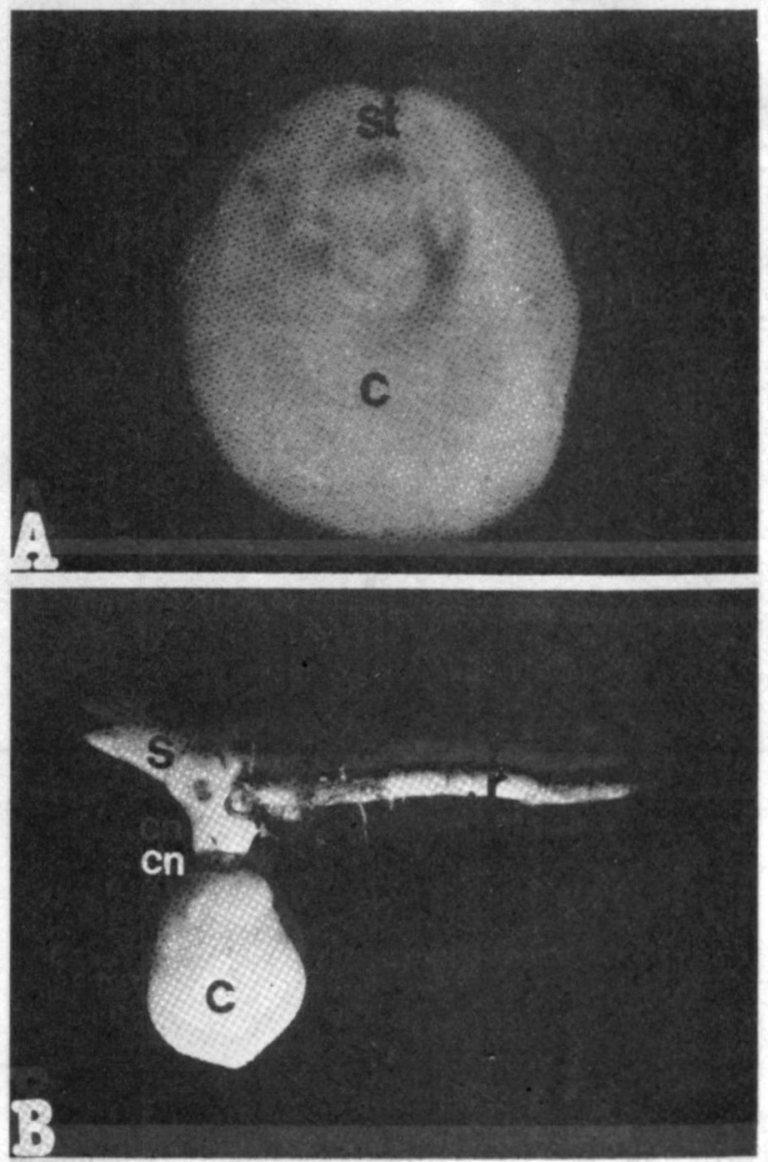

Fig. 2. An immature zygotic embryo (6-7 months postanthesis) and a sprout derived from a zygotic embryo. (A) Immature embryo: st, shoot tip; c; cotyledon. (B) Sprout: c, cotyledon; en, 'cotyledonary node'; s, shoot; r, root.

An early excision of the developing embryogenic callus from the cultured embryo was an important step for continued proliferation of the embryogenic callus. This not only promoted callus proliferation but prevented the engulfment of the embryogenic callus by the fastgrowing cotyledon and the root callus. The callus was maintained by subculturing to a medium of the same composition.

\section{Auxins}

More than $50 \%$ of the cultured embryos produced highly proliferating callus tissues at the optimum levels of 12-20 $\mu \mathrm{M}, 2,4-\mathrm{D}$ (Table II). These optimum levels are in fact very low compared to $10^{-3}-10^{-4} \mathrm{~mol}$ and $30 \mathrm{mg} / \mathrm{l}$ used by Blake [16] and Tisserat [17] for callus proliferation in coconut and Phoenix dactylifera tissues respectively. Higher concentrations ( $30 \mu \mathrm{M}$ and above) not only inhibited callusing but enhanced browning of cultures as well in this investigation. Other auxins tested (IBA, IAA, NAA, NOA, 1-100 $\mu \mathrm{M}$ ) had no favourable effects on cultures. 
Table II. Response of immature zygotic embryos of coconut (6- month-old) to different concentrations of $2,4-D$.

\begin{tabular}{lcc}
\hline $\begin{array}{l}2.4-D \text { Conc. } \\
(\mu M)\end{array}$ & $\begin{array}{c}\text { \% of embryos } \\
\text { producing callus }\end{array}$ & $\begin{array}{l}\text { Callus } \\
\text { proliferation } a\end{array}$ \\
\hline 0 & 0 & No callus \\
4 & 8.3 & + \\
8 & 15.0 & + \\
12 & 52.5 & ++ \\
16 & 56.0 & ++ \\
20 & 55.1 & ++ \\
24 & 18.2 & + \\
30 & 7.9 & + \\
$40-100$ & 0 & No callus \\
\hline
\end{tabular}

a ++ , rapid callusing, subculturable after 2-4 weeks; +, slow callusing, subculturable after 6-8 weeks; no of embryos per treatment, 20.

\section{Developmental stage of the embryo}

The response of embryos of different ages to the culture medium supplemented with 16 $\mu \mathrm{M}$ 2,4-D is shown in Table III. Five-month- old or younger nuts were full of liquid endosperm, with no kernel and the 'embryo' was very poorly differentiated and not visible to the unaided eye. 'Embryos' from these nuts were difficult to excise and hence not cultured. The developing embryo was just visible in 6-7-month-old nuts. It was gelatinous in nature and roughly spherical with a diameter of about $0.2-1.5 \mathrm{~mm}$. These embryos produced fast growing callus when cultured in a medium containing $16 \mu \mathrm{M} 2,4-\mathrm{D}$. Under identical culture conditions, a majority of older embryos ( 8 months old) germinated slowly in culture and only about $30-40 \%$ entered the callus phase. These non-callusing embryos in particular were firm and slightly larger (more than $1.8 \mathrm{~mm}$ in diameter) than the callus producing ones. The 9month-old embryos did not produce callus at all. A majority of them sprouted in culture. Thus the best callus growth was observed in embryos 6-7-month postanthesis and this may be attributed to high cell activity of the 'embryo' during this period. The increase in size of the coconut 'embryo' from 6-7-month postanthesis is about 8-fold and much of the organelle development appears to occur during this period (unpublished data of the authors) (Fig. 2 A). This is probably the period during which 'delayed differentiation of the embryo proper' occurs from one cell of the pluricellular late proembryo [18]. A similar lag phase in the growth of the oil palm embryo was reported recently [19]. After the seventh month, the morphology of the embryo changes dramatically. Callus proliferation from these embryos is poor. Instead, it tends to develop into a normal plant in culture. Thus it is clear that the capacity of the embryo explant to produce embryogenic callus is highly dependant on the developmental stage of the embryo. 
Table III. Response of immature zygotic embryos of different ages to culture conditions. Response is expressed as a percentage of the embryos cultured.

Embryo age (months after

Callus growth

Response to culture anthesis)

Germination

No response $e^{a}$

\begin{tabular}{llll}
\hline 6 & & & \\
7 & +++ & + & ++ \\
8 & +++ & ++ & ++ \\
9 & No callus & ++++ & ++ \\
\hline
\end{tabular}

${ }^{a}+$ less than $20 \% ;++, 30-40 \% ;+++, 50-60 \% ;++++, 63 \%$.

\section{Embryogenesis}

The fast growing callus tissue, following transfer to media containing low 2, 4-D (8 and 2 $\mu \mathrm{M}$ ) and high cytokinins (BAP and kinetin, $10 \mu \mathrm{M}$ each) and incubation under a light intensity of $52 \mu \mathrm{mol} \mathrm{m}-2 \mathrm{~s}-1$ (16-h photoperiod) produced a large number of whitish compact globular somatic embryos. They originated from cells just beneath the 'epidermis' of the convoluted callus (Fig. IE) and resembled the early zygotic embryos of coconut described by Haccius and Philip [18]. Later they emerged to the surface of the callus as tiny globules (Fig. 1D). About $50 \%$ of the callus cultures produced globular embryos and the process was consistent. The presence of auxins, particularly 2,4-D was found to be essential for embryogenesis. Complete withdrawal of 2,4-D from the culture medium suppressed embryogenesis. Exposure of cultures to stronger light $(260 \mu \mathrm{mol} \mathrm{m}-2 \mathrm{~s}-1)$, incubation in liquid media (slow agitation or on filter paper bridges) also suppressed embryogenesis (Table IV). On repeated transfer to a high cyto-kinin (BAP and kinetin $10 \mu \mathrm{M}$ each) and low 2,4-D $(8 \mu \mathrm{M})$ medium, the globular embryos elongated and produced distinct pale green shoots (Fig. IF). The separation of large globular cluster of the callus into smaller groups was found to be essential to prevent the fusion of developing embryos and to enhance further development of globular embryos. Shoot development occurred under the present culture condition in about $22 \%$ of the cultures and 2-6 shoots were observed in each. Shoots were fleshy and resembled those from a zygotic embryo in section (Fig. IG). Further growth was suppressed when sprouts were separated from the callus and cultured in medium of the same composition. Some turned brown. A few proliferated more globules. The shoots did not grow any further in the germination medium of the mature zygotic embryo [20]. At this stage it is not clear whether the cause is intrinsic or an effect of the culture environment.

The culture of immature embryos of coconut as described in this report holds great potential for use in propagation work. Even in many other difficult-to-culture crops, using immature embryos has led to success [21-24]. If successfully developed for the coconut, the technique would provide a practically useful means of micropropagating improved seed material such as that selected for resistance to drought, pests and diseases. By zygotic embryo cloning, planting material may be multiplied uniformly for coconut seed gardens and germplasm banks. 
Table IV Effect of various concentrations of 2,4-D and culture conditions on callus response. The medium contained $10 \mu \mathrm{M}$ each of BAP and kinetin.

\begin{tabular}{lcc}
$\begin{array}{c}\text { Treatment combinations } \\
\text { Light }\end{array}$ & $\begin{array}{c}\text { Response } \\
\left(\mu \mathrm{mol} \mathrm{m} \mathrm{m}^{-2} \mathrm{~s}^{-1}\right)\end{array}$ \\
\hline $\begin{array}{l}\text { 16.0 (control, no } \\
\text { cytokinins) }\end{array}$ & $52,16 \mathrm{~h}$ & Callusing \\
16.0 & $52,16 \mathrm{~h}$ & Callusing \\
8.0 and 2.0 & $52,16 \mathrm{~h}$ & Embryogenesis in about $52 \%$ of cultures \\
0 & $52,16 \mathrm{~h}$ & Embryogenesis inconsistent \\
8.0 and 2.0 & $260,16 \mathrm{~h}$ & \\
8.0 and 2.0 & Continuous darkness & Callusing and greening, no embryogenesis \\
8.0 and 2.0 & & Callusing, embryogenesis inconsistent \\
(liquid no filter & & \\
paper bridges) & $52,16 \mathrm{~h}$ & Poor callusing, no embryogenesis \\
8.0 and 2.0 & & No callusing or embryogenesis \\
(liquid, slow agitation) $51,16 \mathrm{~h}$ &
\end{tabular}

\section{ACKNOWLEDGEMENT}

We are most grateful to Miss K D Cecily for her assistance in performing this investigation. We also gratefully acknowledge the assistance of $\mathrm{Mr} \mathrm{T}$ Weralupitiya, the photographer. Thanks are also due to Prof. A Kovoor and Dr D T Wettasinghe for useful comments in the preparation of the manuscript. This investigation was carried out at the Coconut Research Institute. Lunuwila, Sri Lanka and we thank the Coconut Research Board and the Director for granting permission to publish. Finally we thank Mrs. T M H Fernando for typing assitance.

\section{REFERENCES}

1. V. M. Cutter and K. S. Wilson, Effect of coconut endosperm and other growth stimulants upon the development in vitro of embryos of Cocos nucifera Bot. Gaz.. (Chicago) 115 (1954) 234-239.

2. A. Thomas and K. J. Abraham, A note on the in vitro culture of excised coconut embryos. Ind. Coco. J., 15 (1962) 84-88.

3. C. J. Eeuwens and J. Blake, Culture of coconut and date palm tissue with a view to vegetative propagation. Acta Hortic., 78(1977)277-286. 
4. C. Pannetier and J. Buffard-Morel, First results of somatic embryo production from leaf tissue of coconut, Cocos nucifera L. Oleagineux, 37(1982) 352-353.

5. A. L. Brackpool, R. L. Branton and J. Blake, in: Vasil IK (Ed.) Cell culture and Somatic Cell Genetics of Plants, Vol. 3, Academic press 1986, pp. 207-222.

6. C. R. Raju, P. Prakash Kumar, M. Chandramohan and R. D. Iyer, Coconut plantlets from leaf tissue cultures. J. Plant. Crops 12 (1984) 75-91.

7. R Branton and J. Blake, A lovely clone of coconuts. New Scientist 26(1983)554557.

8. E. V. de Guzman, A. G. del Rosario and E. M. Ubalde Proliferative growths and Organogenesis in coconut embryo and tissue cultures. Philip. J. Cocon. Stud., 3(1978) 1-10.

9. L. D' Souza, Organogenesis in coconut embryo callus, in: A. Fujiwara (Ed.), Proc. 5th Intl. Cong. Plant Tissue and Cell Culture, Maruzen, Tokyo, 1982, pp. 179-180.

10. P. K. Gupta, S. V. Kenkurkar, V.M. Kulkarni, M. V. Shirgurkar and A. F. Mascarenhas, Somatic embryogenesis and plants from zygotic embryos of coconut (Cocos nucifera $\mathrm{L}$ ) in vitro. Plant Cell Rep., 3(1984)222-225.

11. R. A. de Fossard, Tissue Culture for Plant Propagators. University of New England Printery, 1976, pp. 132-149.

12. A. Pretova and E. G. Williams, Zygotic embryo cloning in oil seed rape (Brassica napus L.) Plant Sci., 47(1986) 195-198.

13. B. D. Mohanty, S Dutta and P. D Ghosh, Callus initiation and plant regeneration in. ragi (Eleusine coracana Gaertn). Plant Cell Tissue organ Cult., 5 (1985) 147-150.

14. D. G. He, G. Tanner and K.J. Scott, Somatic embryogenesis and morphogenesis in callus derived from the epiblast of immature embryos of wheat (Triticum aestivum). Plant. Sci. 45 (1986) 119-124.

15. T. D. Ghazi, H. V. Cheema and M. W. Nabors, Somatic embryogenesis and plant regeneration from embryogenic callus of soybean, Glycine max L. Plant Cell Rep., 5 (1986) 452-456.

16. Janet Blake, Tissue culture propagation of coconut, date and oil palm in : John H Dodds (Ed.), Tissue Culture of Trees, Croom Helm, London, 1983, pp. 2 9-50.

17. B. Tisserat, A histological study of development of adventive embryos in organ cultures of Phoenix dactylifera L. Ann. Bot., 46(1980)465-472. 
18. Barbara Haccius and V. J. Philip, Embryo development in Cocos nucifera L: A critical contribution to a general understanding of palm embryogenesis. Plant Syst. Evol., 132(1979) 91-106.

19. D. Ferdinando, J. Hulme and W. A. Hughes, Oil palm embryogenesis: A biochemical and morphological study, in: C. P. Chapman, S. H. Mantell, R. W. Daniels (Eds.), Experimental manipulation of Biochemical Tissues, Longman, London, 1987, pp 135-151.

20. S Karunaratne, C. Kurukulaarachchi, and C. Gamage, A report on the culture of embryos of dwarf coconut, Coconut nucifera L. var nana in vitio. COCOS, 3 (1985) $1-8$.

21. P.J. Dale, Embryoids from cultured immature embryos of Lolium multiflorum Zeit. Pflanzenphysiol., 100(1980) 73-77.

22. S. E. Maddock, V. A. Lancaster, R. Risiott and J. Franklin, Plant regeneration from cultured immature embryos and inflorescences of 25 cultivars of wheat (Triticum aestivum) J. Exp. Bot., 34 (1983) 915-926.

23. C. Y. Lu, S. F. Chandler and I. K. Vasil, Somatic embryogenesis and plant regeneration from cultured immature embryos of Rye (Secale cereale L.). J. Plant Physiol., 115(1984) 237-244.

24. C. S. Goldstein and W. E. Kronstad, Tissue culture and plant regeneration from immature embryo explants of barley, Hordeum vulgare. Theor. Appl. Genet., 71. (1985) 631-636. 